\title{
Performance of broiler chickens fed graded levels of Ripe Plantain Peel Meal (RPPM) as replacement for maize
}

\author{
Agubosi, O. C. P. ${ }^{*}$ Oluwafemi, R. A. and Ibrahim, T. U. \\ Department of Animal Science, Faculty of Agriculture, University of Abuja. Abuja. \\ *Corresponding author. Email: oluchyagubosi@yahoo.com
}

Copyright (C) 2019 Agubosi et al. This article remains permanently open access under the terms of the Creative Commons Attribution License 4.0, which permits unrestricted use, distribution, and reproduction in any medium, provided the original work is properly cited.

Received 7th December, 2018; Accepted 16th January, 2019

\begin{abstract}
This study was conducted to evaluate the performance of broiler chickens fed graded levels of ripe plantain peels meal (RPPM) as replacement for maize. One hundred and fifty day old Anak strain broiler chickens were allotted to five dietary treatments in a completely randomized design. Each treatment was replicated three times with 10 birds per replicate. The test ingredient (RPPM) was replaced at 0, 25, 50, 75 and 100\% levels representing T1, T2, T3, T4 and T5 respectively. The diets were Isonitrogenous (23 and $20 \% \mathrm{CP}$ ) for starter and finisher respectively. Feed and water were provided ad-libitum throughout the study period of 56 days and routine management practices were strictly adhered to. Parameters measured were feed intake and weight gain. Feed conversion ratio, feed cost $/ \mathrm{kg}$ and feed cost $/ \mathrm{kg}$ gain were calculated. Results showed that there were significant $(\mathrm{P}<0.05)$ differences in the final live weight, feed intake, weight gain, feed conversion ratio and feed cost $/ \mathrm{kg}$. Based on this study, RPPM could replace maize up to $75 \%$ which is the inclusion level that gave the best feed conversion ratio and cost efficiency.
\end{abstract}

Keywords: Broiler, ripe plantain peel meal, maize, performance.

\section{INTRODUCTION}

Agriculture continues to play significant roles in the livelihood and economic development of nations all over the world. In Nigeria, the sector is the largest employer of labour with the livestock subsector responsible for the supply of animal protein which is highly essential in human nutrition. One of the challenges facing the livestock sector is the high cost of feed. The stiff competition existing between humans and animals over the limited supply of grains has resulted in a near collapse of the poultry industry in Nigeria (Ahaotu et al. 2009a). It is therefore a common trend for Animal Nutritionist to look for nonconventional feedstuffs that are readily available and cheaper in order to cut down on the feed cost which constitute about 65 to $70 \%$ of the total cost of production (Ologhobo, 1992). This strategy could help reduce the cost of production and ensure cheaper meat production for human consumption.

The economization of feed cost using cheaper and unconventional feed resources (Vasanthakumar et al.,
1999) is an important aspect of commercial poultry production. There are larger numbers of feedstuffs with enormous potentials in Nigeria and one of such is plantain (Musa paradisiaca) peels. Plantain peels is a waste of plantain processing industries, families, road side deep fryers, restaurants, hotels, eateries and if disposed carelessly will pollute the environment. Plantain peel is a good source of energy containing $12 \%$ crude protein, $6 \%$ crude fiber and $2700 \mathrm{Kcal} / \mathrm{kg}$ energy on dry matter basis (Omole et al., 2008). Plantain peels also contains higher levels of minerals such as calcium, iron and phosphorus (Nsa et al., 2010). Almost all parts of the plantain plant are useful. The leaves are used for wrapping, packaging and often used as roofing materials in villages. Recently, plantain peels have been used as feedstuff for growing snails, fishes, rabbits and poultry (Omole et al., 2008).

The use of plantain peels in poultry has been limited because of deleterious effects arising from the presence of tannins. Through sun drying process, the level of tannins 
Table 1. Comparison of the chemical composition of dry plantain peels and maize.

\begin{tabular}{lcc}
\hline Nutrients & Dry Ripe Plantain Peel Meal & Maize \\
\hline Dry matter (\%) & 93.58 & 94.00 \\
Crude protein (\%) & 11.13 & 9.00 \\
Crude fiber (\%) & 6.25 & 2.65 \\
Ether extract (\%) & 6.29 & 4.14 \\
Ash (\%) & 13.01 & 6.89 \\
Nitrogen free extract (\%) & 56.90 & 71.32 \\
Metabolisable Energy (Kcal/kg) & 2946.28 & 3203.51 \\
\hline
\end{tabular}

decreases (Dupiez and De Leener, 2009). Plantain is native to India and is grown most widely in tropical climates. Nigeria is one of the largest plantain producing countries in the world; available data shows that Nigeria produced 2.103 million tons of plantain harvested from 389,000 ha in the year 2004 (FAO, 2005). The objectives of the study were to determine the proximate analysis of ripe plantain peel meal and evaluate the performance of broiler chickens fed percent replacement of ripe plantain peels meal.

\section{MATERIAL AND METHODS}

This study was carried out at the University of Abuja Teaching and Research Farm, main campus, along Airport Road, Abuja-Nigeria. Ripe Plantain peels were collected from local plantain processing industries, road side deep plantain fryers and restaurants in and around Gwagwalada. The plantain peels were sun dried on a clean dry floor. The peels were turned regularly to allow even drying under natural condition and this determines the length of drying period. Regular turning and even drying is required to prevent the growth of microorganism. The dried peels were then crushed in a feed mill to produce the Ripe Plantain Peels Meal (RPPM). A sample of the test ingredient (RPPM) was taken for proximate analysis according to AOAC (1990).

\section{Experimental diets}

Five experimental diets were formulated in which RPPM replaced maize at $0,25,50,75$ and $100 \%$. Diet 1 contained $0 \%$ RPPM and $100 \%$ Maize, diet 2 contained 25\% RPPM and $75 \%$ Maize, diet 3 contained 50\% RPPM and 50\% Maize, diet 4 contained $75 \%$ RPPM and $25 \%$ maize while diet 5 contained 100\% RPPM and 0\% Maize diets.

\section{Experimental animals, design and management}

One hundred and fifty day old Anak strain broiler chicks were randomly allotted into five dietary groups in a completely randomized design (CRD). Each of the treatments was replicated thrice with ten birds per replicate making a total of 30 birds per treatment. Fresh water and feed were provided ad-libitum. Standard management practices were observed throughout the period of 56 days. Birds were managed on deep litter system. The chicks were fed broiler starter from 0 to 4 weeks and broiler finisher 5 to 8 weeks. Data were collected on feed intake and weight gain while feed conversion, feed cost $/ \mathrm{kg}$ and feed cost per kg weight gain were computed.

\section{Statistical analysis}

Data collected were subjected to analysis of variance (ANOVA) using the procedures of SAS (2001) and means were separated using Duncan Multiple Range Test (Duncan, 1955)

\section{RESULTS AND DISCUSSION}

Proximate composition of dry ripe plantain peels and maize are presented in Table 1 . The results showed $11.13 \% \mathrm{CP}, 6.25 \% \mathrm{CF}, 13.01 \%$ ash, $6.29 \mathrm{EE}$, and energy $2946.28 \mathrm{Kcal} / \mathrm{kg}$ for plantain peels and $9.00 \% \mathrm{CP}, 2.65 \mathrm{CF}$, 6.89 Ash, 4.14 EE and energy $3203.51 \mathrm{Kcal} / \mathrm{kg}$ for maize. There were slight variations among most of the nutrients in plantain peels and maize. There was no significant difference $(P>0.05)$ in the mortality rate across the treatments. There was significant difference $(P<0.05)$ in final weight, feed intake, weight gain, feed conversion ratio, feed cost $/ \mathrm{kg}$ and cost $/ \mathrm{kg}$ weight gain across the treatments (Table 2).

A trend was established, such that the higher the level of RPPM inclusion the lower the weight gains. This result compared favorably with the report of Ironkwe and Oruwari (2012) who reported significant differences in feed intake, feed to gain ratio, final live weight and feed cost per $\mathrm{kg}$ weight gain in birds fed diets containing different levels of maize and plantain peels meal. This could also have resulted from the difference in the energy level of ripe plantain peels meal as compared with maize. Also, palatability of the feed could have resulted in the differences in final live weight. There were significant differences $(P<0.05)$ in the feed intake within the treatments. Feed intake decreased marginally with increased level of plantain peels meal but the decrease did not affect the weight gain, rather weight gain was slightly 
Table 2. Growth performance of broiler chickens fed percent replacement of maize with ripe plantain peel meal.

\begin{tabular}{lcccccc}
\hline \multirow{2}{*}{ Parameters } & \multicolumn{7}{c}{ Dietary treatments $(\%)$} \\
\cline { 2 - 7 } & $\mathbf{0}$ & $\mathbf{2 5}$ & $\mathbf{5 0}$ & $\mathbf{7 5}$ & $\mathbf{1 0 0}$ & SEM \\
\hline Initial live weight $(\mathrm{g} / \mathrm{b})$ & 51.00 & 50.00 & 51.00 & 52.00 & 51.00 & 0.32 \\
Final live weight $(\mathrm{g} / \mathrm{b})$ & $1900^{\mathrm{a}}$ & $1695^{\mathrm{b}}$ & $1695^{\mathrm{b}}$ & $1675^{\mathrm{b}}$ & $1535^{\mathrm{c}}$ & 58.27 \\
Daily feed intake $(\mathrm{g} / \mathrm{b} / \mathrm{d})$ & $115.52^{\mathrm{a}}$ & $108.46^{\mathrm{b}}$ & $103.59^{\mathrm{bc}}$ & $100.21^{\mathrm{c}}$ & $102.84^{\mathrm{c}}$ & 2.70 \\
Daily weight gain $(\mathrm{g} / \mathrm{b} / \mathrm{d})$ & $33.02^{\mathrm{a}}$ & $29.38^{\mathrm{b}}$ & $29.36^{\mathrm{b}}$ & $28.98^{\mathrm{b}}$ & $26.50^{\mathrm{c}}$ & 1.04 \\
Feed conversion ratio & $3.50^{\mathrm{a}}$ & $3.69^{\mathrm{b}}$ & $3.53^{\mathrm{a}}$ & $3.46^{\mathrm{a}}$ & $3.88^{\mathrm{c}}$ & 0.08 \\
Feed cost/kg weight gain $(\mathrm{N})$ & $999.87^{\mathrm{b}}$ & $963.35^{\mathrm{b}}$ & $832.89^{\mathrm{a}}$ & $730.50^{\mathrm{a}}$ & $723.50^{\mathrm{a}}$ & 57.39 \\
Mortality $(\%)$ & 3.00 & 0.00 & 1.00 & 0.00 & 0.00 & 1.58 \\
\hline
\end{tabular}

abcd: Means within the same row with superscripts are significantly different $(\mathrm{P}<0.05)$. SEM= Standard Error of Means.

maintained up to $75 \%$ level of RPPM inclusion which is in agreement with the work of Ogunsipe and Agbede (2010) who reported that feed intake decreased marginally with increased level of plantain peels meal but the decrease did not affect the weight gain, rather weight gain increased up to $50 \%$ level of plantain peels meal inclusion.

The differences in feed intake could be attributed to taste and fiber content of the feed, as birds tend to eat less of fibrous diet. Also, the decrease in feed intake could be attributed to decreased palatability of the feed. Fiber creates bulkiness in the gut and this reduces feed consumption of the birds. However, birds consume to satisfy their energy requirements. Daily weight gain decreased with increased level of RPPM in the diets and is comparable with the report of Ogunsipe and Agbede (2010) and this could be attributed to decreased feed intake resulting from high fiber in the diet as the level of RPPM increased. In terms of the efficiency of feed utilization birds fed 0,50 and $75 \%$ RPPM performed significantly $(P<0.05)$ better than other treatments. This result agreed with the findings of Omole et al. (2008) and Agbabiaka et al. (2013).

\section{Conclusion}

Ripe plantain peels had higher crude protein, total ash and ether extract than maize and therefore can replace maize up to $75 \%$ in the diet of broilers. Above this level, performance will be negatively affected. Plantain peels therefore is a good alternative energy source for broilers. The use of this test ingredient on commercial scale requires some logistics that will facilitate easy collection, sorting and drying which may requires artificial source of heat, therefore, the need to further consider the cost implications is required. Also, proper usage of plantain peels results in proper environmental sanitation, effective utilization of agro waste and reduction in the usage of conventional feed stuffs like maize which are costly and highly competitive by man, animals and industries.

\section{CONFLICT OF INTEREST}

The authors declare that they have no conflict of interest.

\section{REFERENCES}

Agbabiaka, L. A., Okorie, K. C., \& Ezeafulukwe, C. F. (2013). Plantain peels as dietary supplement in practical diets for African catfish (Clarias gariepinus Burchell 1822) fingerlings. Agriculture and Biology Journal of North America, 4(2), 155-159.

Ahaotu, E. O., Njoku, P. O., Karsten, K., Yang, N., Ekenyem, B. U., Korie, A. U., \& Madubuike, F. N. (2009). Effects of partial replacement of soybean meal with cassava leaf meal in broiler finisher rations. Animal Production Research Advances, 5(4), 295-299.

AOAC (1999). Official methods of Analysis, 7th Edition. Association of Analytical Chemists, Washington DC.

Duncan, D. B. (1955). Multiple range and f-test. Biometrics, $11(1), 1-42$

Dupiez, H., \& De Leener, P. H. (2009). Africa Gardens and Orchards: Growing vegetables. Revised Edition. Macmillian press London, 334pp.

FAO (2005). Food and Agriculture Organization of United Nations statistics (FAOSTAT database P.I.D. 267).

Ironkwe, M. O., \& Oruwari, B. M. (2012). Effect of replacement levels of maize with plantain peels in broiler finisher diet. Life Sciences Bulletin of Environment, Pharmacology \& Life Sciences, 1(4), 39-42.

Nsa, E. E., Oku, B., Any, M. I., \& Essien, O. E. (2010). Effect of replacement levels of Wheat offal with brewer's dried grain in broiler finisher diets. Proceeding of Nigerian Society for Animal Production, Pp. 14-17.

Ogunsipe, M. H., \& Agbede, J. O. (2010). The replacement value of unripe plantain peels on the growth performance, carcass characteristics and cost implications of rabbit production in the tropical region. Researcher, 2(11), 24-29.

Ologhobo, A. D. (1992). The nutritive value of some tropical (West African) legumes. Poultry Journal of Applied Animal Research, 2(21), 93-104.

Omole, A. J., Ajasin, F. O., Oluokun, J. A., \& Obi, O. O. (2008). Performance characteristics of weaned rabbit fed plantain peel as replacement for maize. Nutrition \& Food Science, 38(6), 559-563.

SAS (2001). User's guide. Statistical analysis System Institute, Inc. Cary., N.C.

Vasanthakumar, P., Sharma, K., Sastry, V. R. B. \& Kumar, R. (1999). Effect of graded levels of neem (Azadirachta indica) Seed Kernel cake on carcass characteristics of broiler rabbits. Asian Autralasian Journal of Animal Science, 12, 1246-1250. 